\title{
Improving Student Vocabulary Mastery Through The Pictionary Words Game in Fifth Grade of Madrasah Ibtidaiyah Tarbiyatul Athfal Sumurber
}

\author{
Author \\ Mohammad Tahmit, Novatrisna Dwi Nastiti, Andi Rahmad Rahim \\ Correspondence \\ University of Muhammadiyah Gresik \\ Email: Tahmit94@gmail.com,novatrisna47@gamil.com
}

\begin{abstract}
:
This study aims to improve the ability of vocabulary in english through the implementation of pictionary words game in elementary school. Basically learning in the classroom must be done in a fun, but the teacher still do not know what techniques are able to attract student learning interest. In addition pictionary words game is also able to make all students active during the learning process. The author conducted a series of processes to identify problems that are happening. From interviews and observationS it can be concluded that the pictionary words game is quite effective in helping students remember vocabularies in English language.
\end{abstract}

Keywords: Game, Pictionary, Vocabulary.

\section{Introduction}

English is the first foreign language that must be taught in Indonesia. Our government has agreed with this since Indonesia's independence from Japanese occupation. English must be taught at all levels of the school from elementary to high school. No exception at the college level even though the department they are taking is not a department that is focused to studying this one foreign language.

The importance of learning English is supported by the Government of Indonesia through the Law on National Education System (2003: 15) "Foreign languages can be used as a language of instruction in certain education units to support students' foreign language skills. That is one of the most important reasons why we must learn English in school.

The next reason why we are obliged to learn English include international languages. This language plays an important role as a main tool of communication between nations. The spread and development of religion, science and technology require us to learn this language. Learning English is also able to provide benefits in the cultural sector. We can easily introduce Indonesian culture if we are able to master it. Mastering English can also make it easier for us to know the technology that currently exists. Almost all technology currently uses English as the main source of information.
Received: 07 Agustus 2019. Accepted: 27 Agustus 2019

In fact, learning English in Indonesia still faces many obstacles. The obstacle that is often faced is the lack of vocabulary mastey. Though there are several components that must be mastered in English, namely grammar, vocabulary, and pronuncation Suyanto (2008: 43). To be understood and accepted as students learning English, all three components must be learned correctly. For madrasah or elementary school students learning English as a foreign language that is not used in the community, the teaching of these three language components needs to be packaged in an integrated and careful manner. However, the main obstacle that occurs in schools is the lack of students' ability in vocabulary, which causes the value of each aspect in English language to include: writing, listening, speaking, reading, not fulfilling KKM targets (Minimum completeness criteria) determined by the school.

In Madrasah Ibtidaiyah Tarbiyatul Athfal Sumurber, Panceng. Many students are still having difficulty learning English, this can be concluded from the lack of vocabulary (vocabulary) in English and the low value of students from the KKM set. The lack of use of English in daily life also impacts on the slow mastery of English. Students still assume that ordinary English is to be used outside of school. When in fact, if you want to be able to use English well, try to use it every day even though only a few vocabularies or vocabulary alone can 
already help to master English. Wilkin in Muh. Iskandar Dzulkurnain (2012: 2) says that without grammar, very little can be conveyed, but without vocabulary, nothing can be conveyed. Very few words without grammar can be conveyed, but without vocabulary, nothing can be conveyed. So to be able to reach vocabulary mastery is very important to support english language skills.

Learning techniques have a very significant influence on students' vocabulary mastery. Students' vocabulary mastery is no longer an obstacle if the teacher is creative in presenting, describing, giving examples, giving lessons to students to achieve this goal. The role of the teacher's creativity in conveying subject matter affects students when following lessons. When students feel bored a teacher must be able to turn on the atmosphere. According to the Dirjen PMTK (Director General of Quality Improvement and Education Personnel) Department of Education and Culture Baedhowi that to foster student interest in learning, a teacher is required to be able to apply interesting ways of learning. While Fakhriyah, Wanabuliandari, \& Ardianti, 2016, maximizing learning using media can produce relevant quality education.

The importance of the role of teacher creativity in conveying subject matter can affect student interest in learning. One of them is by applying games that are integrated with subject matter. Games have many benefits, among others, being able to help improve students' motor skills. Students will become more active and motor skills can develop rapidly. Helping students practice their concentration on the material being taught. The learning process becomes fun, students no longer feel learning is a boring learning process.

The author applies the Pictionary words game as an alternative learning in fifth grade attended by 27 students. Pictionary words game is a play on words invented by Robert Angel with graphic design by Gary Everson and first published in 1985 by Angel Games Inc. (Ravulur, 1997). In playing Pictionary Games, students must make their own drawings or drawings based on the English vocabulary shown on the cards. According to Hinebaugh (2009: 188-193), the Pictionary Game can be used as an excellent teaching tool to develop communication and creative thinking skills; it is suitable for reinforcing ideas in other subjects for students who study visually; it can develop and strengthen a number of facts, figures, or concepts; The Pictionary Rules will focus on developing creativity and natural thinking. Players must not only be creative but must also choose a sketch that will effectively communicate the association to other team members; and very suitable for developing certain grammar and vocabulary mastery.

\section{Method}

A. THE SCEME OF SETTLEMENT PROBLEM

1) Observation - Conducted on March 10, 2019 at the 5th grade Madrasah Ibtidaiyah

Observation

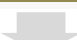

Problem Identification

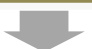

Achievement Targets

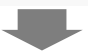

Media Design

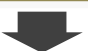

Implementation

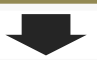

\section{Results}

Tarbiyatul Athfal consisting of 27 students. The first action the writer does is the class observation. In the class the writer is only a passive observer who observes the teacher's teaching methods. From this observation the author can conclude the method applied by the teacher concerned is a traditional teaching method. When asked by the teacher, they said that they had no difficulty in delivering the material, but rather they had difficulty in giving variants to the children. They want to make English subject matter more interesting. This was caused by some students who looked bored with the lesson and lacked focus when the teacher explained the material. 
The writter plans to apply learning methods that can attract students' attention and make them more active in the learning process through educational games such as the pictionary words game. The author continues to collect data through grades and also how the children pronounce English until the interview process for several students after the lesson.

2) Problem Identification - During the observation process, the writter can conclude that students of fifth grade MI Tarbiyatul Athfal have difficulty in receiving subject matter because the teaching methods used by teachers are less effective and tend to be boring. This has an impact on students' interest in learning about English. For the results of interviews conducted by the quizzes on several students, it can be concluded that most students do not like english because they think english vocabulary is difficult to remember.

3) Achievement Targets - Application of Pictionary Words Game was attended by 27 students from fifth grade Madrasah Ibtidaiyah Tarbiyatul Athfal. Through this method the writer hopes to be able to improve the understanding of English vocabulary, especially vocabulary related to animal names and expressions needed to describe them. The writter also hopes this method can increase students' interest in learning English which they previously found difficult and boring.

4) Media Design - To implement there are several supporting tools such as:

a. White cardboard paper, this paper is used as a media to stick to paper that has letters on it.

b. Buffalo paper, then the writer cuts the paper into sections $(5 \mathrm{~cm})$ then writes 1 letter on each paper.

c. Glue / Adhesive, Used as paper adhesive that has been written alphabet.

d. Sound, the writer collected several animal sounds from Youtube and
Google which later used as a clue to guess the name of the animal.

e. Animal picture paper

f. Reward, one of the factors that can attract students to be challenged in the game.

5) Implementation - The writer in this process as an Active Observer directly conveys subject matter to students. With details of activities such as;

a. Material presented by the writer regarding describtive text. Some expressions related to the material are taught to students.

b. Students are divided into 3 groups, the writer explains the rules of the game to students.

c. Furthermore, the writer apply the learning method based on the educational game pictionary words game. At first the participants were given instructions to line up according to the group. The author gives a clue to one of the participants. These clues are in the form of animal sounds or expression sentences to describe the name of an animal that is deliberately kept secret. one by one the participants took turns writing paper with letters. The letter paper was pasted to the paperboard that the previous writer had prepared. It was for the group that made the quickest name for the English-speaking animal that became the winner. This game not only increases student cohesiveness and learning interest but is also able to help students in Spelling english vocabulary.

d. Guessing game uses pictures, sounds or expression, It is a game which requires the participant to guess an answer that the clues have mentioned beforehand. Wirght and Buck said that it is very important, in guessing games and speculating games, one knows something and the other must find what it means. 
Another expert added besides that, the same thing was mentioned by Marriem Webster that game management is a game where one must compete with other people or other groups about guessing something that has been given its instructions. Kipple states that the basic rules of guessing games are very simple, one knows about the vocabulary of something and others try to find it.

6) Results - From the description of the application results above the writer can conclude that the pictionary words game increases student interest in learning from students' enthusiasm when the process is being carried out. Vocabulary of students also increases, this can be seen from the spelling of words and the students' remembrance in the process. The author also conducted interviews with several students. They say that they feel happy to be invited to play guessing games (guessing game) and sticking paper (Pictionary Words Game). On the other hand when applying this method many students from other classes see our activities through obstacles.

\section{Result and Discussion}

According to Nieeven (2010), a media is said to be effective if the use of media can achieve the expected goals. The expected goal in this case is to improve student learning outcomes. Student learning outcomes include three aspects, namely knowledge, skills, and attitudes.

The writer concludes that only two aspects can be achieved from the application of learning methods combined with the educational game pictionary words game. Aspects of knowledge, students are able to master a number of expressions to describe animals and various vocabulary / English vocabulary about animal names. As well as aspects of the attitude shown through group cohesiveness during the game and the sportsmanship of each team. Pictionary words game is also able to increase student interest in learning, it is seen from the enthusiasm of students during the learning process.

\section{Conclusion}

The main purpose of this article is to improve the quality of learning in English using interesting learning methods through the educational pictionary words game. This game is able to improve students' ability to understand english vocabulary as well as descriptive expressions to describe various animals. from the results of interviews can be proven student interest in learning increases because of the implementation of this game. Students who look passive during the observation process look quite active in the game.

\section{Reference}

Chirandon, Amonrat et al. 2010. The Effects of Teaching English through Games. The 2nd International Conference on Humanities and Social Sciences. Songkhla: Prince of Songkla Univeristy

Fadhilah, S. 2011. Teaching english concrete nouns using pictionary game: An eksperimental study with the fourth graders of sdn 01 donowangun talun pekalongan in The academic year 2010/2011. Semarang: IAIN

Genesisd. 2017. 10 ESL Vocabulary Games to Get Your Students Seriously Enganged.Fluentu English,Educator,log.www.fluentu.com/engli sh/educator/blog/esl/tefl/ell/vocabulary,gam es/. Retrieved on 18th February, 2017.

Karam, Misty. 2013. Games Scrabble, Password, and Pictionary as Vocabulary Tools. LoveToKnowCorp.http://boardgames.loveto know.com/Games Scrabble, Password, and Pictionary_as_ Voc abulary_Tools

Marta, Nyikos, \& May Fan. 2007. A review of vocabulary learning strategies: Language learner strategies: Thirty years if research and practice. Oxford University Press

Nation, P. 2001. Learning vocabulary in another language. Cambridge: Cambridge university Press

Robbin, Nicholas. 2013. Pictionary Game Rules.http://www.ehow.co.uk/way 5445906 _pictionary-game-rules.html 
Walisongo.http://library.walisongo.ac.id/digilib/fil es/disk1/104/jtptiain-dl-sitifadhil 5192- 1fileskr-h.pdf. Retrieved on September 25th, 2016.

Gillian Brown and George Yule.1983. Teaching the Spoken Language : An Approach Based on the Analysis of Conversational English. Australia: Cambridge University Press.

Huyen, N.T.T. \& Nga, K.T.T. 2003. Learning vocabulary through games: The effectiveness of learning vocabulary through games. The asian efl journal. https://www.asian-efljournal.com/1493/quarterlyjournal/2003/12/1 earni ng-vocabulary-through-games-the effectiveness-of-learningvocabularythrough games/\#squelch-taas-tab-content03.Retrieved on October 1st, 2016.

Journal of Educational Board Game Design Part One. Rationale, History, Types \& Structures. RetrievedonMarch17,2013.http://edweb.sdsu .edu/courses/edtec670/cardboard/Cardboard Cognition.html 